地域のページ

\title{
福井県木材利用研究会の紹介 \\ Introduction of Research Society of Wood Utilization in Fukui
}

\section{1.はじめに}

「地域のページ」として, 福井県木材利用研究 会の紹介をするに当たり, 当会の発足について次 章で示す前に，それに至った背景を説明いたしま す。

\section{1 福井豪雨}

平成16年 7 月18日，福井県の嶺北地方を中心に 明け方から昼前にかけて猛烈な雨が降り, 河川が 2 個所で破堤するなどして各地で浸水被害が多数 発生しました。その結果, 死者 4 名, 行方不明 1 名, 負傷者19名, 全壊66世帯, 半壊135世帯, 床 上浸水4,052世帯, 床下浸水 9,675 世帯の甚大な被 害が発生し,「平成16年 7 月福井豪雨」と命名さ れました。市街地では河川の堤防決壊等による浸 水被害，また，山間地域では土石流とともに押し 流された流木による二次災害が発生するなどし て，改めて，社会資本整備による都市の防災力の 向上と, 森林整備による水土保全機能の強化の重 要性が認識されることとなりました。

\section{2 足羽川から掘り出された木杭}

福井豪雨は激甚災害に指定されることとなり， 平成16年度より 5 カ年計画で足羽川の河床掘削や 橋梁架替等の工事が進められ，平成21年に竣工し ました。その工事の最中, 河床より昔の橋梁の基 礎や護岸の基礎であった丸太状の木杭が多数発見 されました。

この木杭の健全性を明らかにするため, 平成18 年に水越橋, 幸橋, 木田橋付近より計22本の木杭 を掘り出し, それらの設置環境や採取状況を調査 し, 表面観察, ピロディン試験, 縦圧縮試験によ

\section{吉 田 雅 穂*}

る評価を行いました。本文では, 樹種鑑定の結果,

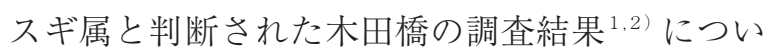
て紹介します。木田橋からは平成18年～20年に直 径 $30 \mathrm{~cm}$ で長さ $3.3 \mathrm{~m} \sim 4.7 \mathrm{~m}$ の木杭が 8 本採取され ました。それらは写真 1 に示すように, 現在の木 田橋近くに架かっていた昭和 24 年施工の銭とり橋 の橋脚基礎であり，設置期間は 57 年〜 59年と推定 されました。木杭表面の観察による腐朽度評価で は, 河床より突出した部分では若干の損傷が確認 されたものの，地中に埋まっていた部分に関して は極めて健全な状態でした。また, 縦圧縮試験の 結果においても, 設計における許容応力度を大き く上回る值を示しました。

これらの評価を, 水越橋上流付近（樹種：カラ マツ属, 設置期間 : 48年) や幸橋付近（樹種：マ ツ属, 設置期間：74年）で掘り出された木杭でも 実施したところ，木田橋の木杭と同様に健全であ る結果が得られました1,2)。

以上の調查結果より, 掘り出された木杭は 48 年

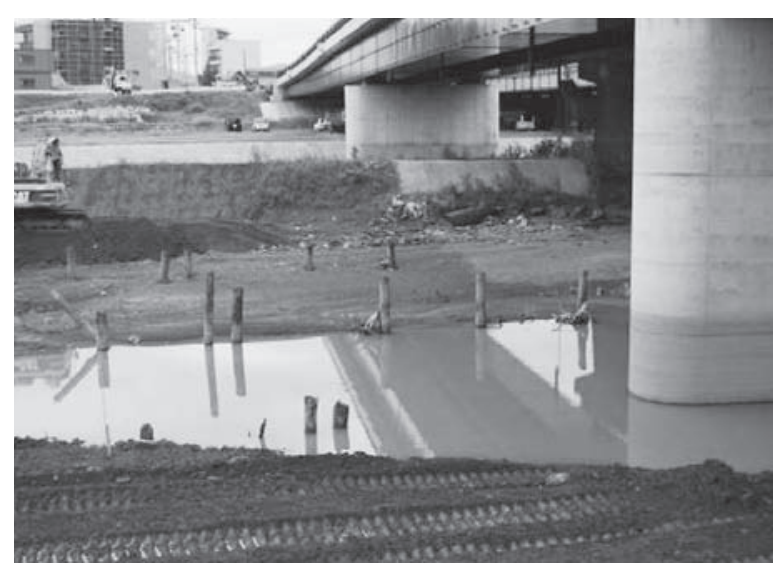

写真 1 木田橋下流側の木杭 
〜 74年もの間, 土中もしくは河川水位以下にあり， いずれの樹種においても腐朽程度は低く，健全な 状態であったことが明らかとなりました。

この研究は, 飛島建設株式会社技術研究所, 福 井県雪対策 - 建設技術研究所 (現：福井県建設技 術研究センター), 福井県総合グリーンセンター, 福井工業高等専門学校の 4 機関が，福井県建設技 術公社の産官学共同研究支援事業の助成を受けて 平成18年度から19年度にかけて行ったものです ${ }^{1)} 。$ これが，著者等が行っている建設事業における木 材利用促進に関する一連の研究の出発点でありま す。丁度この頃は, 平成17年の京都議定書の発効 を受けて，国内外で温暖化対策に関する意識が高 まり始めた時期であり，森林吸収による二酸化炭 素の削減を目的とした森林整備と木材利用の促進 を建設分野でも検討を始めた時期とも重なりま す。

\section{2. 研究会の発足}

平成16年の福井豪雨がきっかけとなり，平成18 年から建設事業に打ける木材利用促進に関する産 官学共同研究が福井県でスタートしました。研究 グループには土木や木材を専門とする研究者がい ましたが，専門が異なると用語も異なります。会 議では門外漢の者同士が互いに勉強しながら議論 を進める状況が続きました。この頃から，土木に おける木材利用を先駆的に行っていた佐賀県の木 材利用研究会との交流が始まりました。また，平 成19年には福井県での共同研究グループの一員で あった飛島建設株式会社の沼田淳紀氏のご尽力に より，木材の供給側である日本森林学会，木材を 加工して供給する側の日本木材学会，ならびに木 材の使用者側である土木学会が共に連携する「土 木に打ける木材の利用拡大に関する横断的研究 会」が発足し，学会レベルの活動もスタートしま した。

この様な状況の中, 福井県における木材利用の 関係者が連携・協調して研究開発を行い，木材利 用を普及・啓発する活動を効率的に行うための研 究会を発足させることが必要との認識に至り, 当 時の福井県雪対策 - 建設技術研究所の久保光研究 員と著者とが発起人となり, 平成 22 年 1 月に福井 県木材利用研究会発足準備会を県内の産官学の関
係者で構成し, 平成 22 年 4 月に研究会を発足させ ました。初代会長には福井大学名誉教授の荒井克 彦先生に就任して頂き，27名の会員で活動をス タートしました。年々会員数は増加し, 平成27年 11月現在での会員数は49名, その内訳は産業界34 名 (26社), 官公庁 12 名 (6 機関), 学校 3 名 (3 機関）となっています。

\section{3. 研究会の活動}

\section{1 定例研究会と見学会}

福井県木材利用研究会は 4 月を年度初めとして 5 月に総会を行い, 表 1 に示すように 5 回の定例 研究会と 1 回の見学会を 2 ケ月に 1 回のペースで 行うことを活動の基本としています。定例研究会 では会員や会員外の方が講師となり, 木材利用に 関する研究成果や業務内容について毎回 2 件の話 題提供を行っています。1 件の発表時間は質疑応 答を含めて約 1 時間であり, 自由な雲囲気で活発 な議論が行われています。会場は事務局でもある 福井県建設技術研究センターを利用させて頂いて います。

見学会は年に 1 回，県内の木材利用に関する施 設や木製構造物の施工現場を見学しています。表 2 に各年度の見学会の内容を示します。また, 写 真 $2 \sim 4$ に現場見学会の様子を示します。

\section{2 キックオフシンポジウム}

研究会を発足した時の活動目的の一つが，木材 利用関係者の連携を強めることでした。すなわち， 川上の林業，川中の木材加工や流通，そして，川

表 1 研究会の活動状況

\begin{tabular}{c|l|c}
\hline 年度 & \multicolumn{1}{|c|}{ 内容 } & 回数 \\
\hline \multirow{4}{*}{22} & 定例研究会 & 6 \\
\cline { 2 - 3 } & 見学会 & 1 \\
\cline { 2 - 3 } & シンポジウム (一般対象) & 1 \\
\hline \multirow{2}{*}{23} & 定例研究会 & 5 \\
\cline { 2 - 3 } & 見学会 & 2 \\
\hline \multirow{2}{*}{24} & 定例研究会 & 5 \\
\cline { 2 - 3 } & 見学会 & 2 \\
\hline \multirow{2}{*}{25} & 定例研究会 & 3 \\
\cline { 2 - 3 } & 見学会, 講演会等 (一般対象) & 3 \\
\hline \multirow{2}{*}{26} & 定例研究会 & 1 \\
\cline { 2 - 3 } & 見学会 & 5 \\
\hline \multirow{2}{*}{} & &
\end{tabular}


表 2 見学会の内容

\begin{tabular}{|c|c|c|}
\hline 年度 & 内容 & 場所 \\
\hline 22 & $\begin{array}{l}\text { 施設（福井県木材流通センター, 美山森林組合 } \\
\text { 加工場） }\end{array}$ & 福井市 \\
\hline \multirow{2}{*}{23} & $\begin{array}{l}\text { 道路構造物を対象とした丸太杭の打設現場 } \\
\text { 製構造物（魚礁） }\end{array}$ & 小浜市 \\
\hline & $\begin{array}{l}\text { 木製構造物の施工現場（パイルネット工法, } \\
\text { 土留め工） }\end{array}$ & 福井市 \\
\hline \multirow{3}{*}{24} & $\begin{array}{l}\text { 舞鶴若狭自動車道三方五湖 PA に打ける丸 } \\
\text { 太杭の打設現場 }\end{array}$ & 若狭町 \\
\hline & $\begin{array}{l}\text { 木製構造物の施工現場（遮音壁, 魚道, 沈床, } \\
\text { 治山ダム, 獣害柵, 水車など) }\end{array}$ & $\begin{array}{l}\text { 福井市 } \\
\text { 永平寺町 }\end{array}$ \\
\hline & 住宅基礎を対象とした環境パイルの打設現場 & 福井市 \\
\hline 25 & $\begin{array}{l}\text { 施設（福井県総合グリーンセンター, 美山 } \\
\text { 森林組合加工場) 木材の伐採現場 }\end{array}$ & $\begin{array}{l}\text { 坂井市 } \\
\text { 福井市 }\end{array}$ \\
\hline 26 & $\begin{array}{l}\text { 施設 (ふくいWOOD バイオマスセンター, } \\
\text { WOOD リサイクルセンターさかい) }\end{array}$ & 坂井市 \\
\hline
\end{tabular}

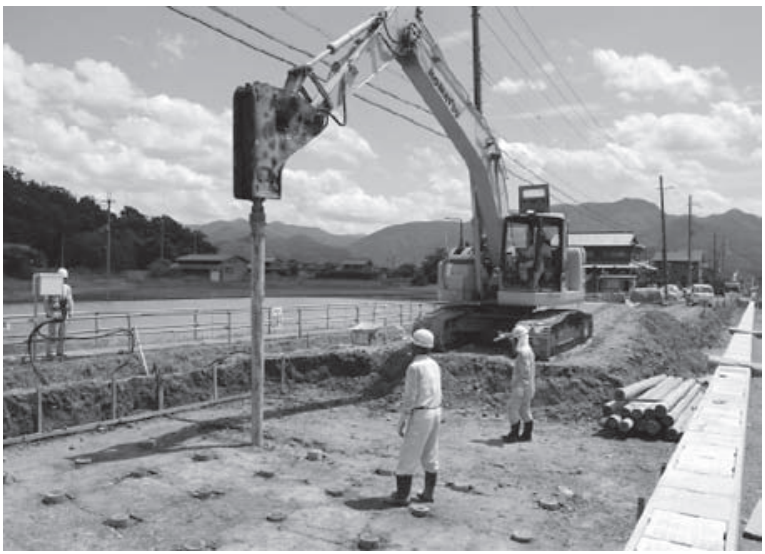

写真2 丸太杭の打設現場見学会

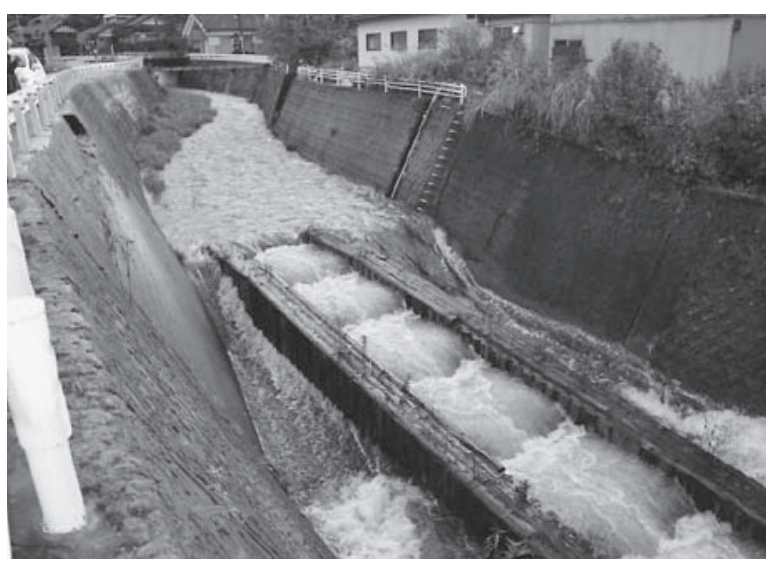

写真 3 木製魚道の見学会

下の建築，土木，農業の木材消費者が共に連携 · 協調し，福井県内の木材利用を促進させていくこ とです。そのため, 平成22年12月11日に福井県国 際交流会館を会場として，「木材利用シンポジウ ム in 福井」を開催しました。行政，森林，建築，

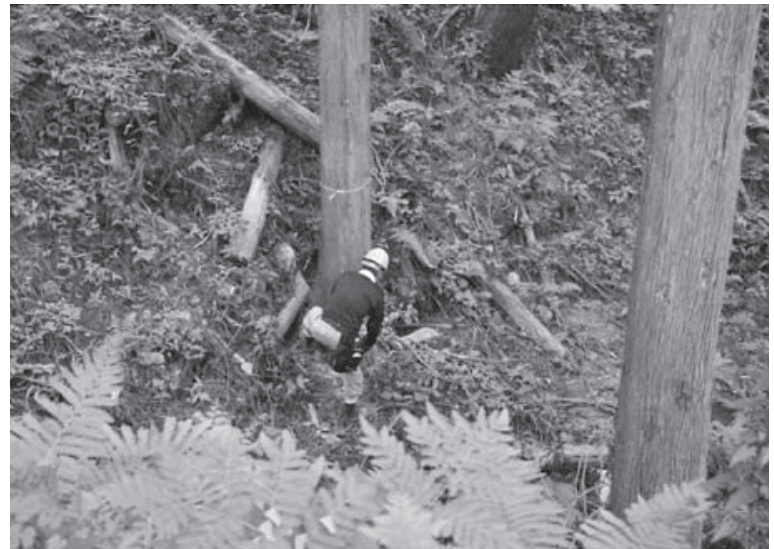

写真 4 木材の伐採現場見学会

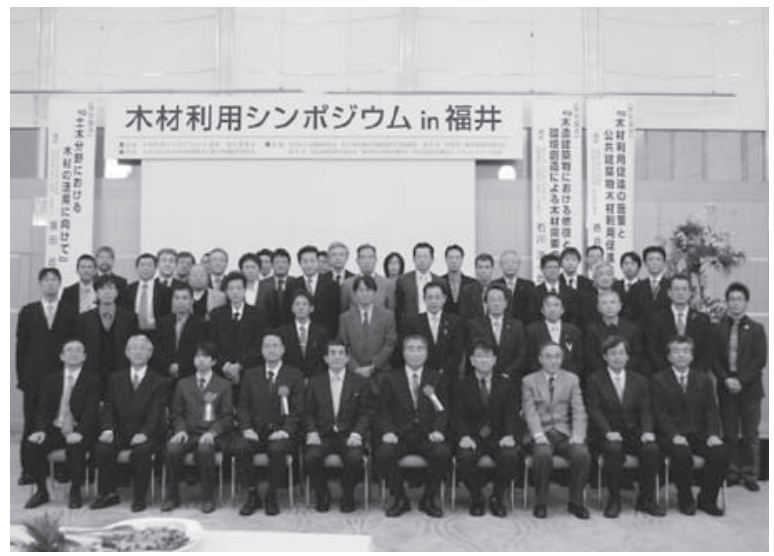

写真 5 懇親会での集合写真

土木，燃料の各分野の専門家や研究者による特別 講演と一般発表，県内外における木材利用の取り 組みを紹介するポスター発表，そして，懇親会を 行い，参加者が広く深く交流する場を提供するこ とができした。なお，本シンポジウムは(社)近畿建 設協会の助成を受けて開催され, 約200名の参加 者を得ました（写真 5 )。

\section{3 分科会活動}

研究会発足 2 年目からは会員の業務に応じた活 動を行うため, 地中利用, 河川・砂防，建築，バ イオマスの 4 つの分科会を設置しました。平成 27 年度からは，それらを土木系 (29名)，建築系（17 名), バイオマス・安定供給（14名）の3つの分 科会に集約して活動を行っています。また, 分科 会の枠組みを超えたタスクフォースを設置し，技 術開発等の研究を行う仕組みを作りました。

\section{4 マニュアルの刊行}

平成23年度は当会のメインテーマを「丸太杭工 法を用いた軟弱地盤対策の設計・施工マニュアル」 


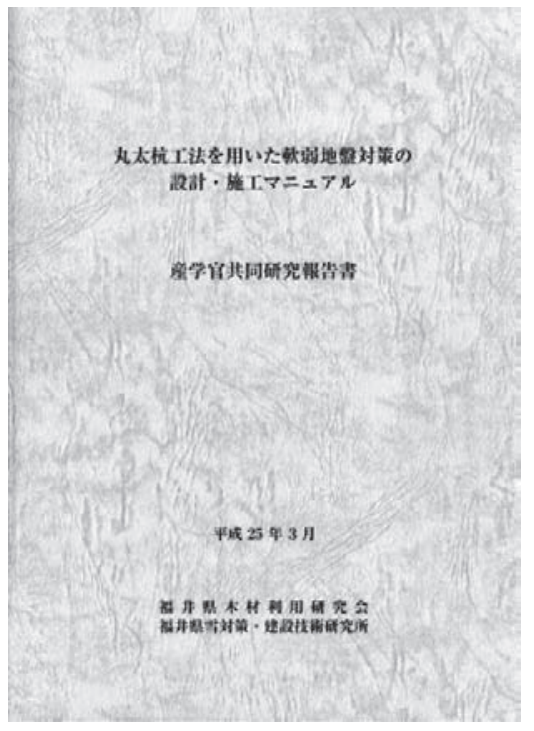

写真 6 マニュアルの表紙

の作成とし，地中利用分科会の会員が中心となり 2 年間の活動を行いました。これは，建設分野で 木材利用が積極的に行われない主な原因が，木材 を利用した構造物の設計・施工の基準が明確にさ れていないことと考えたからです。そこで，木杭 による軟弱地盤対策の研究を長年行っている佐賀 大学名誉教授の三浦哲彦先生や木材利用研究会 （佐賀）会長の宮副一之氏等の協力を得て，プレ キャスト L 型擁壁用マニュアル ${ }^{3)}$ と水路用ボッ クスカルバート用マニュアル4 を基礎資料とし て, 当会や関係機関の研究成果に基づいて, ボッ クスカルバート, 擁壁, 道路盛土の基礎に適用す る設計・施工マニュアル ${ }^{5)}$ を平成25年 3 月に刊行 しました（写真 6 )。

\section{5 普及啓発活動}

研究会発足から 3 年, 会の活動が順調に進み始 めた頃でした。そこで, 平成25年度は「福井県に おける建設事業での木材利用技術の普及啓発」を テーマに，(社)近畿建設協会の助成を受けて表 3 に 示す一般の方々を対象とした講習会や講演会を開 催しました。

写真 7 は小学生と保護者を対象に開催したセミ ナーの集合写真です。福井県総合グリーンセン ターで木材利用による地球温暖化対策と防災に関 する学習を行い, その後, 美山森林組合の協力で 木材伐採の現場見学や間伐材によるプランター作 りを行いました。写真 8 は建設技術者を対象とし た「丸太杭工法を用いた軟弱地盤対策の設計・施
表 3 行事の内容

\begin{tabular}{c|l|c|c}
\hline 開催日 & \multicolumn{1}{|c|}{ 内容 } & 対象 & 参加者 \\
\hline 8月10日 & 親子で学ぶ木材利用セミナー & 一般の親子 & 40 \\
\hline 10 月30日 & 木材利用技術講習会 & 建設技術者 & 69 \\
\hline 12 月17日 & 木材利用技術講演会 & 建設技術者 & 26 \\
\hline 1月31日 & 「丸太杭工法を用いた軟弱地盤対策 & 建設技術者 & \multirow{2}{*}{111} \\
\hline 2月5日 & の設計・施工マニュアル」講習会 & & \\
\hline
\end{tabular}

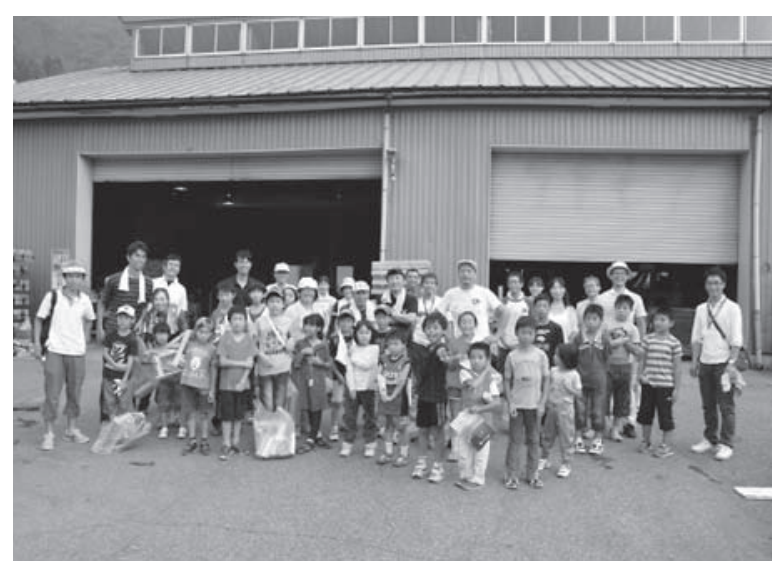

写真 7 親子対象のセミナー

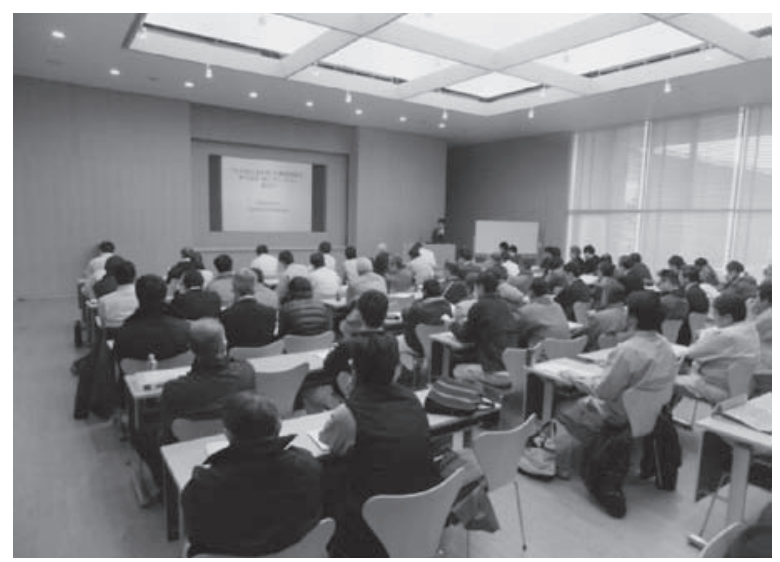

写真 8 技術者対象の講習会

エマニュアル」講習会の様子です。福井県の嶺北 と嶺南の 2 地域で開催し, 官公庁や建設コンサル タント，施工業の技術者が多数参加しました。ま た,この講習会用に同マニュアル（100頁）の「抜 粋版 (68頁)」と「設計事例 (50頁)」を作成し, 講習会で配布しました。

平成 27 年度には (一社) 北陸地域づくり協会の 助成を受けて, 写真 9 に示す研究会の活動を紹介 するリーフレットを作成し, フクイ建設技術フェ ア等のイベントで配布して県内業界に周知する活 動を行いました。 


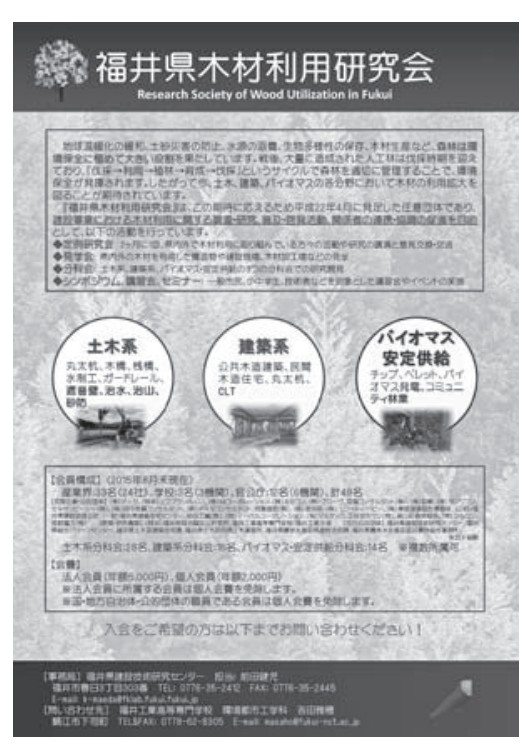

写真 9 研究会紹介リーフレット

\section{4. おわりに}

以上, 福井県木材利用研究会について会の発足 から現在までの活動について紹介しました。発足 当初, 土木で地震工学を専門とする筆者がこの様 な活動を行っていることに対し「なぜ木材？」と いう問いを度々かけられました。しかし，今では 「なぜ」の問いかけはなくなりました。

昭和30年に閣議決定された「木材資源利用合理 化方策」によって国内の木材消費が抑制されるよ うになってから四半世紀，平成 9 年には「京都議 定書」が採択され温室効果ガスの吸収源対策とし て森林の役割が示され, 平成21年に発表された「森 林・林業再生プラン」では木材自給率 $50 \%$ を目指 す目標が出されました。また，平成22年には「公 共建築物等に打ける木材の利用の促進に関する法 律」が施行し, 平成23年には「森林・林業基本計 画」が閣議決定され，住宅や土木用資材への木材 利用について技術開発と普及を推進する方針が示 されました。さらに，東日本大震災をきっかけと して平成25年には「国土強勒化基本法」が成立し, 森林整備や国土保全のために木材の積極的な利用 を促進することが国の方針として示されました。

建設事業における木材利用の研究から10年, 福 井県木材利用研究会の発足から 6 年, ようやく, これまでの活動が社会に役立つものへと移行して いることを実感しています。
福井県出身の著名人に漢字学者の故白川静博士 がいます。博士は三千年以上前の古代中国の殷王 朝に生まれた漢字の成り立ちを研究し, 多くの漢 字辞典を作られています。それによると、「木」 の古代文字は木の幹と枝と根を表す「表」と書か れていたそうです。これは，目に見える形を具体 的に描いた象形文字です。「木偏」と組み合わせ た会意文字は「杭, 板, 柵, 架, 栈, 棚, 棒, 棟, 楼，槽，橋，欄」など多数あります。これらは， 昔は木で作られていた物ですが, 現在では木以外 の材料で作られることが多くなってしまいまし た。しかし今, これらの漢字本来の材料で作る時 代が再来したといえるでしょう。

最後に, 当研究会の発足から現在にいたるまで, 研究会の会員の皆様はもち万んのこと, 共同研究 を行ってきた研究者の皆様, 学会等の活動でご支 援を頂いた皆様，その他の関係者の皆様に心より 感謝申し上げます。

なお, 当会の活動の詳細はホームページ (http: //toshichan.be.fukui-nct.ac.jp/yoshida/mokuzai/) で紹介していますので是非ご覧ください。

\section{参考文献}

1) 飛島建設, 福井工業高等専門学校, 福井県: 脱地球温暖化社会へ向けた建設工事への木材利 用に関寸る調査・研究, 福井県建設技術公社, 109p., 2008.

2 ）吉田雅穂, 沼田淳紀, 上杉章雄, 久保光, 源 済英樹, 野村崇 : 足羽川で掘り出された木杭の 健全度調査, 土木学会第62回年次学術講演会, pp.183-184, 2007.

3 ) 佐賀県県土づくり本部, (社)佐賀県県土づくりコ ンサルタンツ協会, 財佐賀県土木建築技術協会: プレキャスト $\mathrm{L}$ 型擁壁 $(\mathrm{H} \leqq 2 \mathrm{~m})$ の木杭 - 底 盤系基礎～設計マニュアル（第 1 版）～, 2008.

4 ) 佐賀県県土づくり本部, (社佐賀県県土づくり コンサルタンツ協会, (財)佐賀県土木建築技術協 会: 水路用ボックスカルバートの木杭一底盤系 基礎〜設計マニュアル（改訂版）～, 2009.

5 ) 福井県木材利用研究会, 福井県雪対策 - 建設 技術研究所：丸太杭工法を用いた軟弱地盤対策 の設計・施工マニュアル, 産官学共同研究報告 書, 100p., 2013.

（2015.11.30受付） 